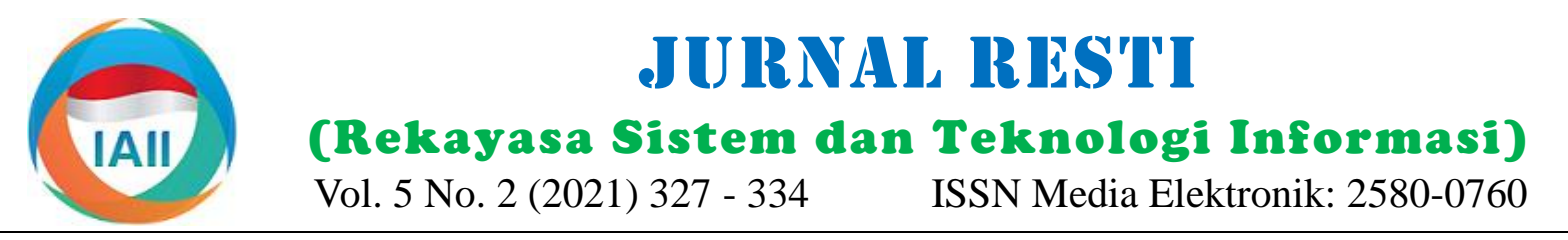

\title{
Implementasi Firebase Realtime Database pada Aplikasi FeedbackMe sebagai Penghubung Guru dan Orang Tua
}

\author{
Khairun Nisa Meiah Ngafidin ${ }^{1}$, Artika Arista ${ }^{2}$, Rona Nisa Sofia Amriza ${ }^{3}$ \\ ${ }^{1,3}$ Sistem Informasi, Fakultas Informatika, Institut Teknologi Telkom Purwokerto \\ ${ }^{2}$ Sistem Informasi, Fakultas Ilmu Komputer, Universitas Pembangunan Nasional Veteran Jakarta \\ ${ }^{1}$ nisa@ittelkom-pwt.ac.id, ${ }^{2}$ artika.arista@upnvj.ac.id, ${ }^{3}$ rona@ittelkom-pwt.ac.id
}

\begin{abstract}
The necessity of learning assistance for elementary student is to ensure that students can absorb the learning well. In order to keep track of the student's progress, the teacher needs to know how and what the student has done while at home. The FeedbackMe application was created to become a liaison between teachers and parents during distance learning. Firebase Realtime Database is implemented to support messages to be delivered quickly. The purpose of this study is to implement the Firebase Realtime Database into the FeedbackMe application to support remote student learning. The system development method used is the Waterfall method which is a systematic and sequential method. The results of this study indicate that all the features in the application and also the application of Firebase can run properly and correctly. Meanwhile, testing of respondents regarding user satisfaction results in the amount of $89.28 \%$ from teacher, and respondents from parents got $89.73 \%$ satisfaction.
\end{abstract}

Keywords: Firebase, Feedback, Realtime Database, Communication, Distance Learning.

\begin{abstract}
Abstrak
Proses pendampingan belajar siswa sekolah dasar oleh guru sangat diperlukan untuk memastikan siswa dapat menyerap pembelajaran dengan baik. Namun, dengan ditiadakannya pembelajaran tatap muka, maka proses pendampingan pun berpindah ke orang tua. Agar tetap dapat mengetahui perkembangan siswa tersebut, maka guru perlu tahu bagaimana dan apa saja yang telah dilakukan oleh siswa tersebut selama di rumah. Aplikasi FeedbackMe dibuat untuk menjadi penghubung antara guru dan orang tua siswa selama pembelajaran jarak jauh. Agar data yang dimasukkan langsung tersampaikan oleh guru maupun orang tua, maka Firebase Realtime Database diimplementasikan dalam aplikasi ini guna mendukung pesan yang masuk agar cepat sampai karena sifat database ini yang real time. Tujuan dari penelitian ini adalah untuk mengimplementasikan Firebase Realtime Database ke dalam aplikasi FeedbackMe guna mendukung pembelajaran siswa secara jarak jauh. Metode pengembangan sistem yang digunakan adalah metode Waterfall yang merupakan metode sistematis dan berurutan. Hasil penelitian ini menunjukkan bahwa semua fitur dalam aplikasi dan juga penerapan Firebase dapat berjalan dengan baik dan benar. Sedangkan pengujian terhadap responden mengenai kepuasan pengguna didapatkan hasil sebesar $89.28 \%$ dari pengujian terhadap guru, dan mendapatkan hasil tingkat kepuasan sebesar $89.73 \%$ dari pengujian terhadap orang tua.
\end{abstract}

Kata kunci: Firebase, Feedback, Realtime Database, Komunikasi, Pembelajaran Jarak Jauh.

\section{Pendahuluan}

Teknologi yang saat ini tersedia memberikan banyak pilihan bagi guru maupun orang tua untuk dapat saling terhubung melalui teknologi tersebut. Komunikasi secara digital ini dapat memberikan kesempatan kepada guru untuk dapat berkomunikasi ke orang tua siswa secara cepat dan nyaman [6]. Terlebih lagi situasi dan kondisi yang tengah memburuk di kala pandemi membuat siapapun berusaha untuk bisa beradaptasi dan menyesuaikan diri dengan kondisi yang ada. Guru dan siswa yang biasanya saling berinteraksi tatap muka dan berhadapan langsung, dengan kondisi siswa kini harus terpisah dan mengembalikan keadaan tersebut ke orang tua untuk dapat diamati dan diberikan pendidikan dengan baik. Tentu berbeda perlakuan yang diberikan oleh orang tua dan guru ketika memberikan pendidikan ke siswa, namun permasalahan tersebut bukan menjadi halangan untuk terus dapat memberikan yang terbaik ke mereka. Dengan diterapkannya komunikasi digital yang

Diterima Redaksi: 31-01-2021 | Selesai Revisi: 05-04-2021 | Diterbitkan Online: 30-04-2021 
baik antara orang tua dan juga guru maka dapat (NoSQL) dan dibangun oleh Google dengan memberikan kontribusi yang baik pula bagi meminimalkan proses coding, sehingga pengembang perkembangan holistik siswa [1]. aplikasi lebih dapat fokus pada pembuatan aplikasi [7].

Media digital dianggap sebagai tempat yang lebih efisien, cepat, efektif, juga nyaman digunakan daripada menggunakan model konvensional [2]. Model konvensional seperti bertatap muka mengharuskan guru untuk dapat bertemu dengan siswa maupun orang tua. Di tengah keterbatasan kegiatan yang sedang dilakukan akhir-akhir ini, harus ada solusi untuk mengatasi permasalahan dari model konvensional yang sering digunakan tersebut. Permasalahan lain seperti kegiatan kunjungan dari guru ke rumah-rumah siswa yang dilakukan pada jenjang Sekolah Dasar, bisa saja memperburuk keadaan dan juga kurang efektif untuk dilaksanakan di tengah pandemi. Memang, interaksi secara online memiliki kekurangan fitur penting bagi hubungan dua orang manusia, seperti kontak mata, bahasa tubuh dan lain sebagainya sehingga kegiatan ini dinilai memiliki kekurangan dalam hal interaksi dibanding tatap muka [3].

Orang tua menjadi salah satu mitra kerja pokok bagi guru dalam mendidik anak, sehingga komunikasi antara orang tua dan guru sangat dibutuhkan untuk menyamakan persepsi kedua belah pihak. Keduanya harus saling membantu satu sama lain dan mengetahui bagaimana upaya penanganan pembinaan anak di sekolah, bagaimana kegiatan belajar mengajarnya, maupun pola komunikasinya. Begitu pun sebaliknya, sekolah juga harus mengetahui apa dan bagaimana yang terjadi di rumah terkait dengan kegiatan anak, aktivitas belajar, maupun interaksinya dengan sesama anggota keluarga [4]. Banyak guru yang merasa prihatin terhadap kesulitan yang dialami terutama karena ketidaktahuan mereka dalam menyampaikan pengajaran yang berkualitas dalam keadaan berjarak, tanpa tanggapan verbal maupun non verbal dari kegiatan yang biasa dilakukan di kelas [5]. Pemanfaatan teknologi menjadi jembatan bagi orang tua dan guru dalam mendidik siswa terutama bagi siswa Sekolah Dasar yang masih perlu didikan lebih besar dibandingkan siswa SMP maupun SMA. Salah satu yang dapat dilakukan adalah dengan agar proses komunikasi a membuat suatu perangkat lunak yang dapat tersampaikan secara real-time, maka Firebase Realtime memfasilitasi antara orang tua dan guru. Sejauh ini, Database dipilih sebagai penunjang aplikasi. Tujuan komunikasi antara orang tua dan guru telah dilaksanakan penelitian ini adalah untuk menerapkan Firebase dengan menggunakan aplikasi pesan seperti WhatsApp. Realtime Database pada aplikasi penghubung orang tua Namun, untuk membuat suasana pembelajaran lebih dan guru yaitu FeedbackMe. Pembuatan aplikasi eksklusif dan tertata maka perlu adanya tempat tersebut diharapkan dapat memberikan manfaat bagi tersendiri untuk komunikasi guru dan orang tua agar kedua belah pihak yaitu guru dan orang tua siswa, prosesnya lebih rapi dan jelas.

Dalam pembuatan aplikasi berbasis android, basis data diperlukan guna menyimpan data yang berhubungan dengan aplikasi yang dibuat tersebut. Firebase Realtime Database dipilih sebagai tempat untuk menyimpan data untuk kemudian ditampilkan di antar muka aplikasi. Firebase merupakan basis data yang tidak berelasi menyimpan datanya pada format JSON (JavaScript Object Notation) sehingga tidak perlu menerapkan query untuk melakukan proses input, ubah, hapus, maupun penambahan data [8]. Firebase juga memiliki latensi yang rendah sehingga efektif digunakan untuk aplikasi seluler dan dapat melakukan sinkronisasi secara real-time kepada pengguna [9]. Dengan adanya fitur tersebut, maka diharapkan Firebase dapat menjadi pendukung aplikasi agar informasi yang didapat oleh orang tua siswa dapat langsung tersampaikan oleh guru, sehingga dapat langsung diberikan feedback.

Teknologi Firebase saat ini telah banyak diimplementasikan oleh pengembang aplikasi Android. Begitu juga dengan penelitian yang berkaitan dengan Firebase, seperti studi yang dilakukan oleh George ichard Payara [10] yang meneliti tentang "Penerapan Firebase Realtime Database pada Prototype Aplikasi Pemesanan Makanan Berbasis Android". Penulis membuat aplikasi dengan menerapkan teknologi Firebase Realtime Database berbasis Android karena Firebase memiliki banyak fitur seperti authentication, database, storage, hosting, dan pemberitahuan, sehingga dapat mempermudah pelanggan dalam melakukan proses pemesanan makanan pada Warung Lawas tanpa harus menunggu waktu yang lama. Selain itu, penelitian yang serupa juga dilakukan pula oleh Ilham Firman Maulana [11] tentang "Penerapan Firebase Realtime Database pada Aplikasi E-Tilang Smartphone berbasis Mobile Android". Pada penelitian ini penulis membuat suatu aplikasi E-Tilang dengan menggunakan teknologi Firebase Realtime Database. Dari beberapa penelitian sebelumnya diketahui bahwa implementasi Firebase dapat diterapkan dibanyak studi kasus di berbagai macam area penelitian. Namun dalam penerapannya masih sedikit yang meneliti dan diimplementasikan pada dunia pendidikan.

sehingga proses pengembangan pendidikan siswa dapat terpantau dengan baik oleh guru kelas meskipun dipisahkan oleh jarak, waktu, dan tempat.

\section{Metode Penelitian}

Dalam melaksanakan penelitian ini, metode Waterfall dipilih sebagai metode yang digunakan dalam 
pengembangan sistem. Metode waterfall sendiri Perangkat lain yang dibutuhkan adalah tempat untuk merupakan metode yang paling umum dan klasik juga menguji aplikasi. Emulator atau disebut juga sebagai disebut dengan siklus hidup sekuensial linier. Metode ini AVD (Android Virtual Device) dan juga dapat memang membatasi ruang gerak pengembang dan menggunakan Smartphone Android sebagai tempat pengguna karena semua perbaikan hanya dapat untuk melakukan pengujian aplikasi ketika AVD tidak dilakukan ketika sistem tersebut selesai dibuat, sehingga dapat digunakan di laptop pengembang.

metode Waterfall baik digunakan untuk sistem yang pendefinisian awalnya sudah jelas [12]. Bahkan karena

\subsection{Desain}

keberhasilan metode Waterfall, banyak perusahaan Tahap desain yaitu proses merencanakan hal-hal yang pengembang perangkat lunak dan juga produsen industri akan dibuat dalam penelitian. Perencanaan menerapkan metode ini sebagai kerangka pengembangan sistem dibuat dengan menggunakan Use pengembangan utama mereka untuk melakukan proses Case Diagram. Use Case ini dibuat untuk perencanaan, pembangunan, maupun pemeliharaan menggambarkan siapa saja yang berperan dalam sistem produk [13]. Gambar 1 menunjukkan proses siklus dan juga peran apa yang dilakukan dari pengguna hidup menggunakan Waterfall yang dimulai dari tersebut. Masing-masing aktor dapat memiliki spesifikasi kebutuhan sampai dengan pemeliharaan.

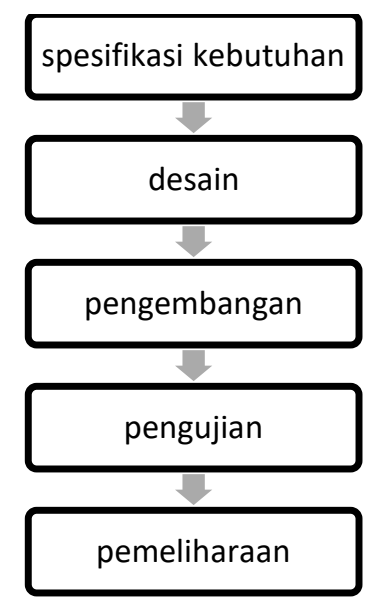
aktivitasnya masing-masing. Namun dalam penelitian ini, hanya terdapat dua aktor dengan lima macam aktivitas secara keseluruhan yang bisa dilakukan.

Selain menggunakan Use Case, dalam penelitian ini juga akan menerapkan Diagram Aktivitas untuk memberikan gambaran tentang bagaimana aktivitas sistem ketika diakses oleh pengguna. Hal tersebut dimulai dari bagaimana pengguna login ke sistem sampai dengan mengisikan form dan juga menampilkan hasil inputan. Semua proses tersebut dijabarkan dengan Diagram Aktivitas pada kegiatan-kegiatan seperti memasukkan data feedback oleh guru maupun kegiatan memasukkan data siswa ke dalam aplikasi oleh orang tua.

\subsubsection{Diagram Use Case}

Gambar 1. Siklus Hidup Pengembangan Sistem Menggunakan Waterfall

\subsection{Spesifikasi Kebutuhan}

Pada tahap spesifikasi kebutuhan, proses yang dilakukan adalah mengidentifikasi apa saja yang dibutuhkan dalam proses pengembangan aplikasi. Aplikasi ini membutuhkan data berupa komponen penilaian apa saja yang diperlukan untuk diketahui oleh guru. Dalam penelitian ini, komponen penilaian akan dibuat dalam bentuk form, sehingga diharapkan dapat memudahkan orang tua untuk memasukkan datanya. Penelitian dilakukan pada kelas tertentu yaitu pada kelas 3 Sekolah Dasar, sehingga komponen utama yang diperlukan adalah Penilaian Membantu Orang Tua, Pembiasaan Diri, Tematik, Matematika, Bahasa Inggris, dan PJOK.

Pada sisi pengembangan aplikasi, beberapa hal yang dap diperlukan 作 adalah IDE (Integrated Development Environment) melihat data penilaian. Orang tua dapat mengakses input Android Studio yaitu tempat menuliskan kode untuk penilaian yang digunakan untuk memasukkan data siswa kemudian menjadi sebuah aplikasi yang diinginkan. dan juga melihat data feedback yang dimasukkan oleh Firebase Realtime Database yaitu sebagai basis data guru.

penyimpanan data aplikasi, Firebase ini bisa diakses melalui Firebase Console berbasis web.

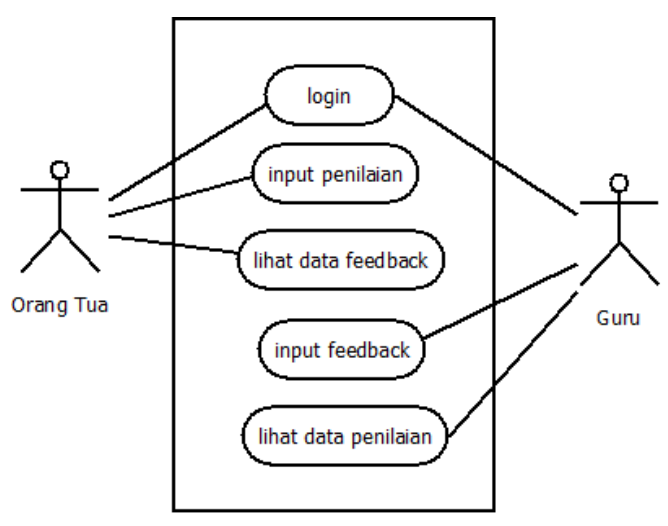

Gambar 2. Diagram Use Case Aplikasi FeedbackMe

Gambar 2 menampilkan Use Case Diagram dari sistem FeedbackMe. Di sistem ini terdapat dua aktor yang dapat mengakses aplikasi, yaitu guru dan orang tua. Guru Agar dapat memberikan feedback dan memasukkan data penilaian, maka kedua aktor harus melakukan proses login terlebih dahulu dengan menggunakan username 
dan password. Proses login juga akan divalidasi oleh Pada Gambar 4, orang tua juga harus melakukan proses sistem, jika benar maka akan berlanjut ke halaman login ke aplikasi sebelum melakukan input data. Setelah selanjutnya, namun jika salah maka pengguna harus proses memasukkan data selesai, maka data tersebut memasukkan kembali hingga benar.

\subsubsection{Diagram Aktivitas}

Gambar 3 menunjukkan proses diagram aktivitas guru. tersimpan dan orang tua dapat memilih untuk keluar aplikasi.

Pada gambar tersebut guru akan melakukan proses login Tahap pengembangan yaitu tahapan dimana proses dengan menggunakan username dan password yang pengimplementasian dijalankan. Pada tahap ini, segala ditentukan, lalu setelah berhasil masuk, maka langsung macam kebutuhan dan juga perencanaan yang telah diarahkan ke menu halaman data siswa. Namun, jika dibuat, akan diimplementasikan ke dalam penulisan pengguna salah memasukkan username dan kode atau sintaks. Data yang didapatkan dari guru akan passwordnya maka akan muncul pemberitahuan bahwa dibuat formnya dengan menggunakan IDE Android pengguna salah memasukkan data. Dari data siswa Studio. Pembuatan form itu sendiri terdiri dari tersebut, guru dapat memilih untuk memberikan komponen edittext, textview, dan button.

feedback untuk kemudian datanya akan tersimpan di Firebase.

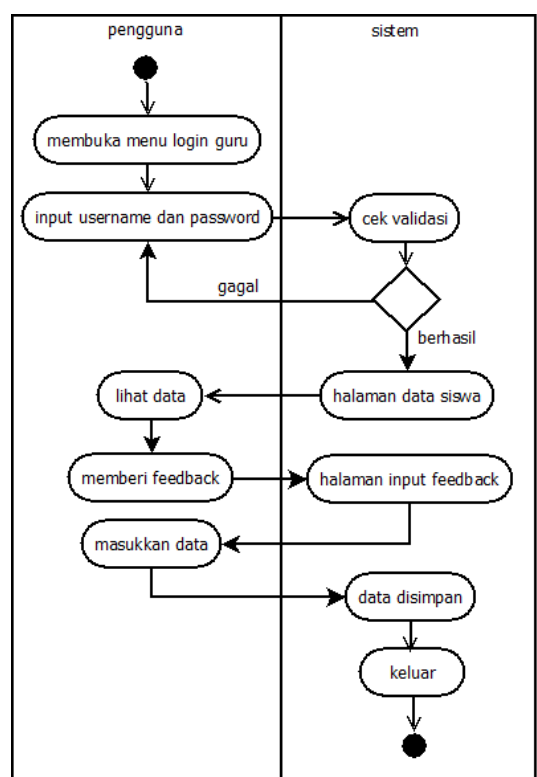

Gambar 3. Diagram Aktivitas dari Menu Feedback Guru

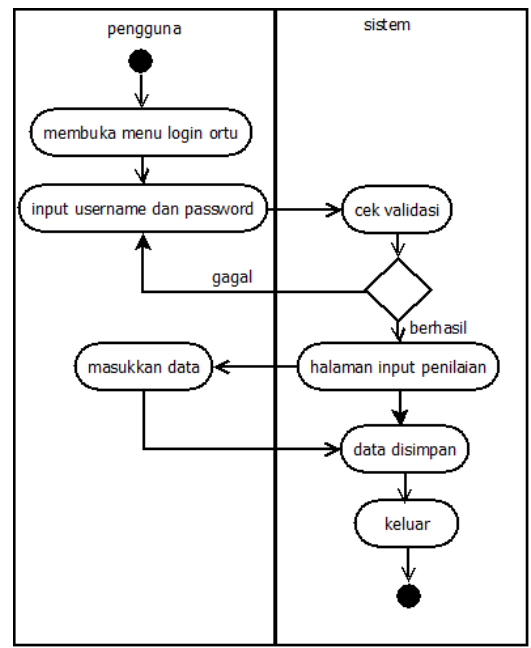

Gambar 4. Diagram Aktivitas dari Menu Input Penilaian Siswa
Disamping itu, Firebase diterapkan dengan menuliskan deklarasi dan juga kode untuk menyambungkan antara aplikasi dan Firebase yang dilakukan di Firebase Console. Ketika semua program telah ditulis dengan baik, maka terakhir hasilnya akan dimunculkan dalam emulator Android untuk melihat seberapa jauh aplikasi dapat diterjunkan ke pengguna.

\subsection{Pengujian}

Tahap pengujian dilakukan untuk melakukan uji coba terhadap aplikasi yang telah dibuat dengan menggunakan metode pengujian black box. Pengujian dengan menggunakan black box akan menguji bagaimana aplikasi tersebut berjalan, apakah sudah sesuai yang diinginkan atau tidak. Pengujian ini lebih menekankan pada hasil akhir aplikasi dengan melihat beberapa komponen atau bagian.

Hal yang diuji adalah fitur atau menu yang terdapat dalam aplikasi, seperti menu lihat data penilaian, menu input data feedback, menu input data penilaian, menu login, dan menu lihat data feedback. Selain itu, pengujian sistem terhadap pengguna juga dilakukan untuk mengetahui tingkat kepuasan pengguna terhadap aplikasi ini. Pengujian ini dilakukan dengan menyebarkan kuesioner yang membahas tentang tampilan dan juga efektivitas aplikasi dengan memanfaatkan skala Likert.

\subsection{Pemeliharaan}

Tahap pemeliharaan yaitu tahapan terakhir yang ada dalam metode Waterfall. Proses ini merupakan tahapan untuk melakukan perbaikan jika terdapat kesalahan yang terjadi pada sistem. Pemeliharaan juga dilakukan dengan melihat layanan-layanan dukungan pada aplikasi tersebut, seperti Firebase.

Proses pemeliharaan dapat terjadi jika dalam pengimplementasiannya ada beberapa bagian yang kurang menurut pengguna maupun menurut pengembang aplikasi itu sendiri. Hal tersebut dapat berupa penambahan fitur atau menu, perubahan tulisan, 
penambahan pengguna, pemberian hak akses, maupun 3.2. Antarmuka Sistem perubahan warna yang ada pada antarmuka aplikasi dan tombol.

\section{Hasil dan Pembahasan}

Hasil dari penelitian ini berupa aplikasi android yang mengimplementasikan Firebase Realtime Database dengan hasil keluaran berupa tampilan aplikasi disertai dengan hasil pengujian yang dilakukan pada responden. Proses secara keseluruhan aplikasi digambarkan dengan menggunakan bisnis proses sistem seperti ditunjukkan pada Gambar 5.

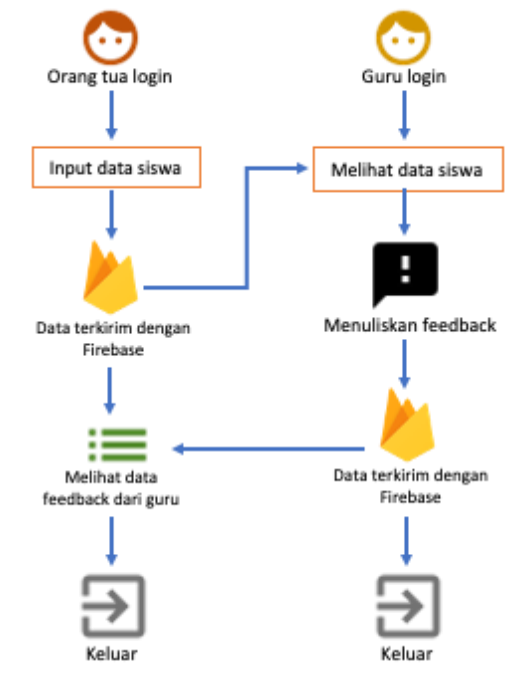

Gambar 5. Bisnis Proses Aplikasi FeedbackMe

\subsubsection{Tampilan Menu Utama Orang Tua}

Gambar 7 (a) menunjukkan tampilan utama dari menu orang tua setelah proses login selesai dilaksanakan. Orang Tua dapat memilih apakah akan memasukkan data ataupun melihat data feedback yang diberikan oleh guru. Pertama kali yang bisa dilakukan oleh orang tua adalah memasukkan data siswa ke aplikasi, sehingga data hasil masukan tersebut bisa dapat langsung diberikan feedbacknya oleh guru. Ketika guru telah selesai menilai dan memberikan feedbacknya, maka orang tua dapat melihat hasil tersebut dengan mengakses menu yang kedua yaitu Melihat Data Feedback.

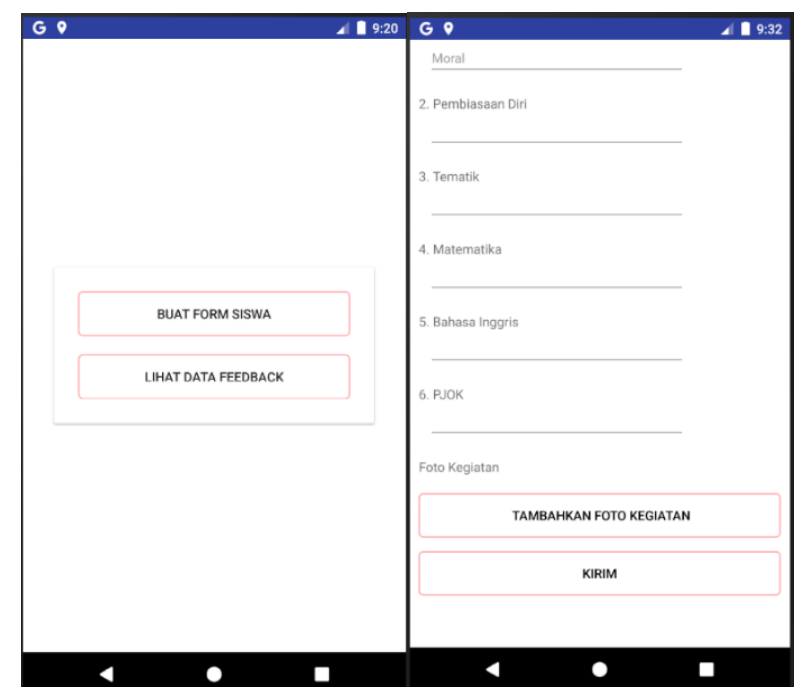

\subsection{Penerapan Firebase Realtime Database}

Penerapan Firebase diawali dengan membuat project di Firebase Console. Setelah itu, untuk menambahkan realtime database, maka perlu adanya pendeklarasian dependensi untuk library Android Realtime Database di Gradle modul. Gambar 6 menunjukkan deklarasi dari Firebase yang diperlukan agar aplikasi dapat menerapkan database tersebut. Proses deklarasi ini penting untuk dilakukan agar aplikasi dapat menerapkan database tersebut dengan baik.

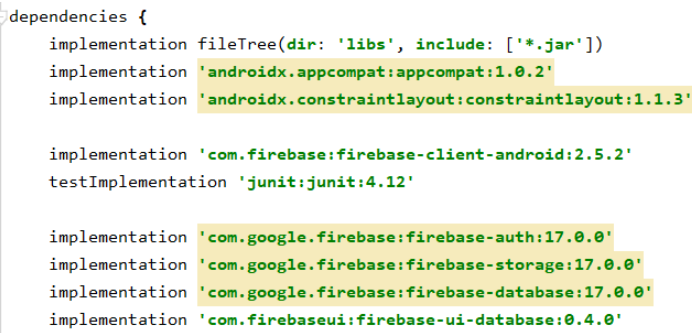

Gambar 6. Deklarasi untuk Menerapkan Firebase dalam Koding

Setelah Firebase berhasil diterapkan di dalam pengkodean, maka proses dilanjutkan dengan membuat secara keseluruhan tampilan sistem dan juga kode untuk menghubungkannya dengan Firebase. (a)

(b)

Gambar 7. (a) Tampilan Utama, (b) Input Penilaian

Orang tua dapat memasukkan data melalui menu Buat Form Siswa seperti ditunjukkan pada Gambar 7 (b). Orang tua dapat pula memasukkan gambar yang berupa foto kegiatan siswa ketika sedang dalam pembelajaran di rumah, maupun foto-foto yang berkaitan dengan tugas siswa. Setelah proses input selesai dilakukan, maka orang tua pun dapat langsung mengirimkannya dengan menekan tombol kirim di bagian bawah layar.

\subsubsection{Tampilan Menu Utama Guru}

Menu guru akan menampilkan daftar siswa-siswa secara keseluruhan. Guru dapat melihat secara detail isi dari data tersebut dengan memilih salah satu nama siswa dan kemudian sistem akan menunjukkan kembali daftar data yang telah dimasukkan oleh orang tua. Daftar data tersebut ditunjukkan dengan menggunakan tanggal sebagai pembeda antara masukan hari ini maupun hari yang lalu.

Tanggal yang ada pada daftar gambar 8 (a) berarti bahwa pada tanggal tersebut lah orang tua memasukkan data siswanya ke sistem. Gambar 8 (b) menunjukkan tampilan dari detail data siswa yang dimasukkan oleh 
orang tua. Guru juga dapat melihat gambar yang diunggah oleh orang tua dengan menekan tombol lihat gallery.

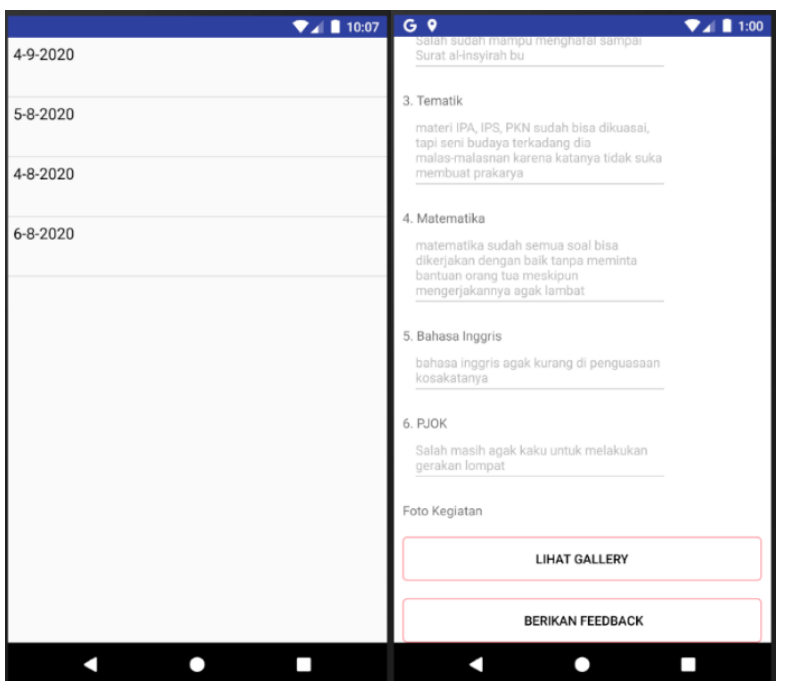

(a)

(b)

Gambar 8. (a) Daftar Penilaian, (b) Isi Penilaian

Pada menu Lihat Gallery tersebut berisi gambar-gambar yang berkaitan dengan proses belajar mengajar siswa selama di rumah. Selain itu, guru dapat memberikan feedback terhadap hasil pelaporan orang tua dengan menekan tombol feedback di bagian bawah tampilan. Ketika guru memilih untuk memberikan feedback, maka guru akan langsung diarahkan ke halaman form input feedback yang berisi kolom nama siswa serta kolom untuk menuliskan isi dari feedback tersebut.

\subsection{Pengujian Sistem}

Pengujian dilakukan untuk mengetahui apakah sistem yang dibuat dapat berfungsi dengan baik ataukah tidak. Pengujian ini dilakukan dengan menggunakan salah satu metode pengujian perangkat lunak, yaitu pengujian black box. Hal yang diuji terdiri dari menu-menu yang terdapat pada aplikasi seperti menu input data, input feedback, menu login, lihat data penilaian siswa, dan menu lihalt data feedback. Di bawah ini merupakan detail dari bagian yang diuji, butir uji dan juga hasil pengujian dengan menggunakan black box terhadap aplikasi FeedbackMe:

Tabel 1. Tabel Pengujian Aplikasi FeedbackMe

\begin{tabular}{|c|c|c|}
\hline $\begin{array}{l}\text { Bagian yang } \\
\text { diuji }\end{array}$ & Butir uji & Hasil uji \\
\hline $\begin{array}{l}\text { Menu input data } \\
\text { penilaian siswa }\end{array}$ & $\begin{array}{l}\text { Menampilkan form } \\
\text { untuk memasukkan } \\
\text { data yang bentuknya } \\
\text { berupa edittext dan } \\
\text { form upload gambar }\end{array}$ & $\begin{array}{l}\text { Sistem dapat } \\
\text { menampilkan form } \\
\text { untuk input data } \\
\text { dan dapat } \\
\text { mengirimkannya ke } \\
\text { Firebase }\end{array}$ \\
\hline $\begin{array}{l}\text { Menu } \\
\text { feedback }\end{array}$ & $\begin{array}{l}\text { Menampilkan form } \\
\text { untuk memasukkan } \\
\text { data feedback }\end{array}$ & $\begin{array}{l}\text { Sistem dapat } \\
\text { menampilkan form } \\
\text { untuk } \\
\text { menambahkan } \\
\text { feedback dan dapat }\end{array}$ \\
\hline
\end{tabular}

mengirimkannya ke Firebase

\begin{tabular}{|c|c|c|c|}
\hline $\begin{array}{l}\text { Menu lihat data } \\
\text { feedback }\end{array}$ & $\begin{array}{l}\text { Menampilkan } \\
\text { feedback }\end{array}$ & daftar & $\begin{array}{lr}\text { Sistem } & \text { dapat } \\
\text { menampilkan } & \text { data } \\
\text { feedback } & \text { yang } \\
\text { berasal } & \text { dari } \\
\text { Firebase } & \\
\text { Sidem } & \end{array}$ \\
\hline Menu login & $\begin{array}{l}\text { Menampilkan } \\
\text { login }\end{array}$ & form & $\begin{array}{l}\text { Sistem dap } \\
\text { menampilkan for } \\
\text { login dan dap } \\
\text { masuk ke sister } \\
\text { baik sebagai oran } \\
\text { tua maupun sebag. } \\
\text { guru }\end{array}$ \\
\hline $\begin{array}{l}\text { Menu lihat data } \\
\text { penilaian siswa }\end{array}$ & $\begin{array}{l}\text { Menampilkan } \\
\text { siswa } \\
\text { penilaiannya } \\
\text { dimasukkan ole } \\
\text { tua }\end{array}$ & $\begin{array}{r}\text { daftar } \\
\text { yang } \\
\text { sudah } \\
\text { orang }\end{array}$ & $\begin{array}{l}\text { Sistem dap } \\
\text { menampilkan daft } \\
\text { nama siswa }\end{array}$ \\
\hline
\end{tabular}

Tabel 1 menunjukkan daftar pengujian yang dilakukan pada sistem aplikasi FeedbackMe menggunakan pengujian black box. Dari hasil pengujian diketahui bahwa semua menu dan fitur dalam sistem ini berfungsi dengan baik dan dapat menampilkan semuanya dengan sukses.

\subsection{Pengujian Sistem ke Pengguna}

Pengujian sistem ke pengguna perlu dilakukan untuk mengetahui bagaimana kepuasan pengguna jika sistem ini jika diterapkan dan dimanfaatkan. Selain itu, dalam pengujian ini juga dapat melihat seberapa baik tampilan maupun performa dari aplikasi tersebut. Dalam penelitian ini dilakukan pengujian aplikasi dengan memberikan kuesioner mengenai sisi tampilan dan juga keefektifan aplikasi terhadap kebutuhan pengguna.

Tabel 2. Daftar Pertanyaan Kuesioner untuk Guru

\begin{tabular}{ll}
\hline Variabel & Pertanyaan \\
\hline Tampilan & - Aplikasi ini memiliki tampilan yang user- \\
& friendly \\
- Aplikasi ini memiliki tulisan yang mudah dibaca & - Aplikasi ini memiliki tombol dan tulisan yang \\
& jelas \\
- Aplikasi ini memiliki warna yang ramah di mata & \\
Efektivitas & Aplikasi ini membantu mengetahui progress \\
& belajar siswa asecara real-time \\
& Aplikasi ini bisa menjadi jembatan antara guru \\
& - Aplikasi ini memberi kemudahan dalam \\
& berkomunikasi dengan orang tua \\
- Aplikasi ini mempermudah pekerjaan guru \\
\\
dalam memantau siswa
\end{tabular}

Tabel 3. Daftar Pertanyaan Kuesioner untuk Orang Tua

\begin{tabular}{ll}
\hline Variabel & Pertanyaan \\
\hline Tampilan & - Aplikasi ini memiliki tampilan yang user- \\
& friendly \\
& - Aplikasi ini memiliki tulisan yang mudah dibaca \\
& - Aplikasi ini memiliki tombol dan tulisan yang \\
& jelas \\
& - Aplikasi ini memiliki warna yang ramah di mata
\end{tabular}

DOI: https://doi.org/10.29207/resti.v5i2.2909

Lisensi : Creative Commons Attribution 4.0 International (CC BY 4.0) 


\section{Efektivitas - Aplikasi ini memudahkan proses pelaporan progress siswa secara real-time \\ - Aplikasi ini membantu mendapatkan feedback dari guru secara real-time \\ - Aplikasi ini dapat menjadi jembatan penghubung antara orang tua dan guru \\ - Aplikasi ini memudahkan orang tua dalam mendapatkan respon feedback dari guru}

Tabel 2 dan 3 menunjukkan daftar pertanyaan yang harus dijawab baik bagi guru dan juga orang tua. Pada bagian Tampilan hal yang menjadi fokus pertanyaan bagi keduanya sama karena tampilan kedua pengguna tersebut menjadi satu kesatuan dan yang berbeda hanya pada menu dan isinya saja.

\section{Pada bagian pertanyaan mengenai efektivitas,} pertanyaannya disesuaikan pada masing-masing pengguna. Pengguna guru efektivitasnya mengarah ke kebermanfaatan aplikasi tersebut pada pembelajaran dan pengontrolan siswa. Sedangkan pada orang tua lebih ditekankan pada manfaat dari sisi kemudahan dalam mengetahui hasil feedback dari guru.

Bobot penilaian dalam pengujian ini adalah Sangat Setuju bernilai 4, Setuju bernilai 3, Kurang Setuju bernilai 2 dan Tidak Setuju bernilai 1. Kemudian responden yang ikut serta mengisi kuesioener totalnya 14 responden dengan rincian 7 responden guru dan 7 responden orang tua. Hasil pengujian ini ditunjukkan pada Gambar 9.

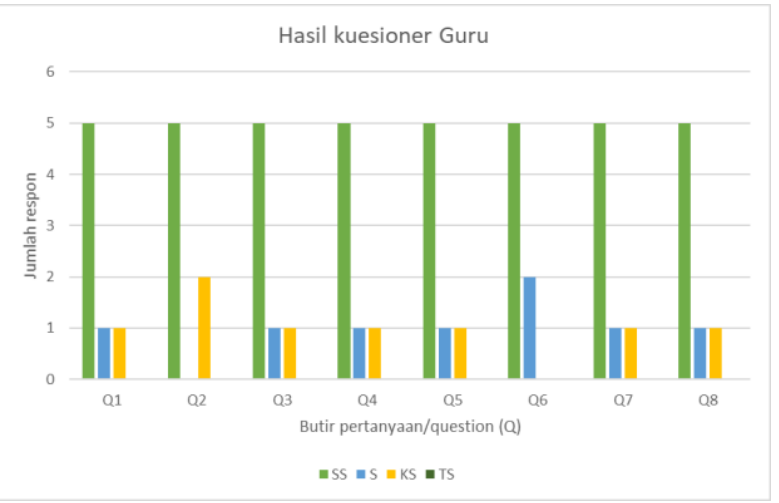

Gambar 9. Hasil Pengujian Aplikasi untuk Guru

Gambar 9 menunjukkan bahwa pengujian dengan responden 'guru' menghasilkan hasil rata-rata kepuasan sebesar $89.28 \%$ dengan dominan hasil menyebutkan Sangat Setuju. Sedangkan pengujian dengan responden 'orang tua' menghasilkan keseluruhan rata-rata kepuasan sebesar $89.73 \%$ seperti ditunjukkan pada Gambar 10.

Dari kedua hasil kuesioner menunjukkan bahwa pengujian dengan responden 'guru' dan responden 'orang tua' menghasilkan rata-rata kepuasan yang hampir sama yaitu $89 \%$ di mana hal ini menunjukkan respon positif dari kedua belah pihak.

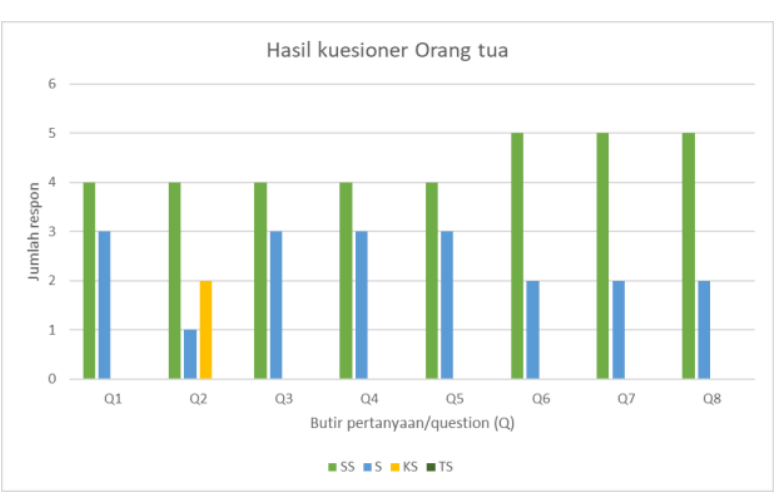

Gambar 10. Hasil Pengujian Aplikasi untuk Orang Tua

\section{Kesimpulan}

Berdasarkan hasil penelitian yaitu mengenai penerapan Firebase Realtime Database pada aplikasi FeedbackMe, dapat disimpulkan bahwa aplikasi tersebut dapat dijalankan dengan baik dan juga dapat menerapkan Firebase sebagai tempat penyimpanan data. Kemudian dari kedua hasil kuesioner menunjukkan bahwa pengujian dengan responden 'guru' dan responden 'orang tua' menghasilkan rata-rata kepuasan yang hampir sama yaitu $89 \%$ di mana hal ini menunjukkan respon positif dari kedua belah pihak.

Berdasarkan fakta tersebut, adanya aplikasi ini dapat membantu guru untuk bisa memantau perkembangan siswa meskipun tidak saling bertatap muka. Selain itu, bagi orang tua pun feedback dari guru dapat menjadi pertimbangan dan arahan agar proses belajar mengajar di rumah tetap dapat terlaksana dengan baik seperti saat di sekolah. Adanya penerapan Firebase membuat proses feedback guru ke orang tua menjadi lancar dikarenakan prosesnya yang real time dan langsung tersampaikan ke orang tua begitu guru menekan tombol kirim di sistem.

\section{Daftar Rujukan}

11] A.J. Kuusimaki, U. M. Lotta, dan K. Tirri, "Parents' and Teachers' Views on Digital Communication in Finland," Hindawi: Education Research International, 2020.

[2] M. M. Bordalba, dan J. G. Bochaca, "Digital Media for FamilySchool Communication? Parents' and Teachers' Beliefs," Comp. Edu..

[3] E. Patrikakou, "Relationships among Parents, Students, and Teachers: The Technology Wild Card," Proc. - Soc. Behav. Sci., vol. 174, pp.2253-2258, 2015.

[4] A. Pusitaningtyas, "Pengaruh Komunikasi Orang Tua dan Guru terhadap Kreativitas Siswa. In: International Seminar on Generating Knowledge Through Research," UUM-UMSIDA. Universiti Utara Malaysia, Malaysia 25-27 Oktober 2016.

[5] S. Bubb, dan M. A. Jones, "Learning from the COVID-19 homeschooling experience: Listening to pupils, parents/carers and teachers," Improv. Sch., vol. 23, no. 3, pp. 209-222, 2020.

[6] N. Bosch, S. Bosch, K. Cline, S. Hochhalter, A. Rieland, E. Takekawa, dan T. Walther, "The Effects of Parent-Teacher Communication using Digital Tools in Early Elementary and Middle School Classrooms," [Online] Tersedia di: https://sophia.stkate.edu/maed/231, 2017. [Accessed 25 Januari 2021] 
[7] M. Ohyver, J. V. Moniaga, I. Sungkawa, B. E. Subagyo, dan I. A. [10]G. R. Payara dan R. Tanone, "Penerapan Firebase Realtime Chandra, "The Comparison Firebase Realtime Database and MySQL Database Performance using Wilcoxon Signed-Rank Test," 4th International Conference on Computer Science and Computational Intelligence, Yogyakarta 12-13 September 2019, 396-405.

[8] C. Khawas dan P. Shah, "Application of Firebase in Android App Development - A Study," Inter. J. Comp. App. vol 179, no. 46, pp. 49-53, 2017.

[9] B. L. Jones, "Introduction to Firebase. Database Journal: Knowledge for Database Professionals [Online] Tersedia di: https://www.databasejournal.com/features/mysql/introductionto-firebase.html. [Accessed on 25 Jan 2020] Database pada Prototype Aplikasi Pemesanan Makanan berbasis Android," J. T. Informatika Sist. Info., vol. 4, no. 3, pp. 397-406, 2018.

[11]I. F. Maulana, "Penerapan Firebase Realtime Database pada Aplikasi E-Tilang Smartphone berbasis Mobile Android," $J$. RESTI: Reka. Sistem Tek. Info., vol. 4, no. 5, pp.854-863, 2020.

[12]P. S. Ganney, S. Pisharody, dan E. Claridge, "Clinical Engineering (Second Edition) A Handbook for Clinical and Biomedical Engineers: Chapter 9 (Software Engineering). Elsevier, pp. 131168, 2020.

[13] Y. Bassil, "A Simulation Model for the Waterfall Software Development Life Cycle,” Inter. J. Eng. Tech., vol. 2, no. 5, 2012 